\title{
ERRATUM
}

\section{Equol elicits estrogenic activities via PI3K/akt pathway in the estrogen receptor-positive MCF-7 cells}

\author{
Huaqing Liu ${ }^{1, *}$, Chunyan $\mathrm{Hu}^{2, *}$, Xuesen $\mathrm{Wu}^{1}$ \& ${\mathrm{Zhong} \mathrm{Li}^{2}}^{2}$ \\ (C) The Korean Society of Toxicogenomics and Toxicoproteomics and Springer 2014
}

Erratum to: Mol Cell Toxicol (2014) 10:285-291

DOI 10.1007/s13273-014-0032-9

In Fig. 2A, in the online version of the original publication, the unit for Equol in the figure should be ' $\mu \mathrm{M}$ '. The corrected figure appears below.

The online version of the original article can be found under doi: 10.1007/s13273-014-0032-9.

${ }^{1}$ Department of Preventive Medicine, Bengbu Medical College, Anhui, Bengbu, 233030, China; and

${ }^{2}$ Department of Nutrition and Food Hygiene, School of Public Health,

Nanjing Medical University, Nanjing, 211166, China

*These authors contributed equally to this work.

Correspondence and requests for materials should be addressed to

Z.Li(凹uiuclz@126.com) 
A

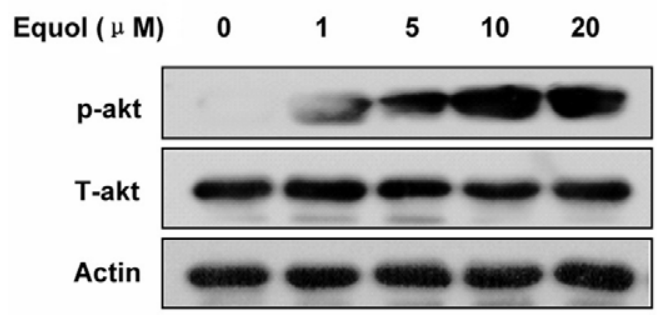

C

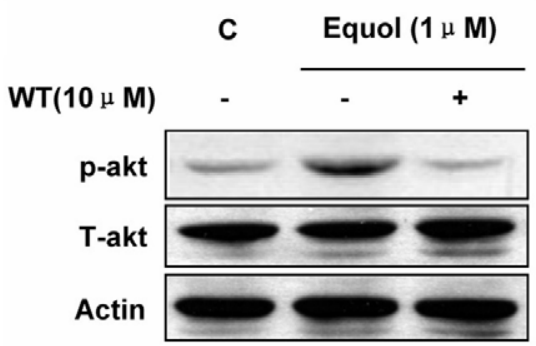

B

Equol (1 $\mu \mathrm{M})$

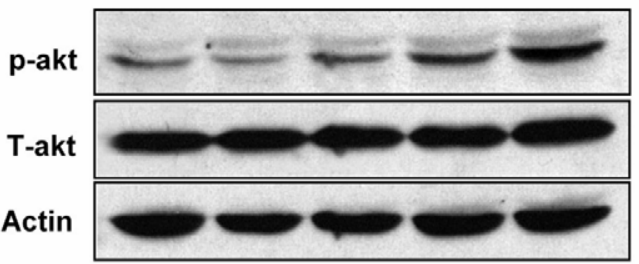

D

Equol (1 $\mu \mathrm{M})$

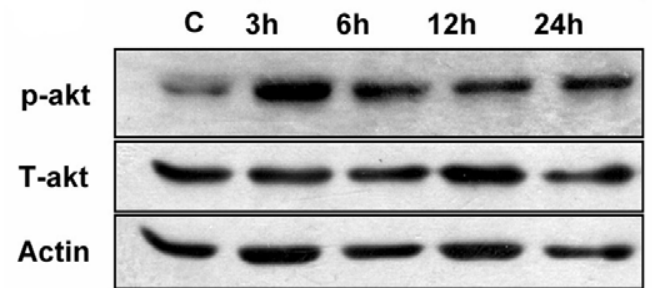

Figure 2. Equol activates the PI3K/Akt signal pathway in MCF-7 cells. MCF-7 cells were treated with increasing concentrations of equol (1-20 $\mu \mathrm{M})$ for 24 hours $(\mathrm{A})$, equol (1 $\mu \mathrm{M})$ for 15-120 min (B) or 3-24 h (D) before harvesting for lysis. After MCF-7 cells were pretreated by PI3K inhibitor, wortmannin (WT, 0 or $10 \mu \mathrm{M}$ ) for $6 \mathrm{~h}$, they were exposed to $1 \mu \mathrm{M}$ equol for $24 \mathrm{~h}(\mathrm{C})$. Lysates were immunoblotted with specific antibodies against the total or the phosphorylated form of Akt. Akt and phospho-Akt levels were normalized to $\beta$-actin protein levels. Histograms represent densitometric measurements of specific bands using actin level as a control. Experiments were repeated twice with similar results, and representative blots are presented. 